\title{
A Review of Packaging Options for Tomato Smallholder Farmers in Sub-Saharan Africa
}

\author{
Tadeo Mibulo, Noble Banadda, Nicholas Kiggundu \\ Department of Agricultural and Biosystems Engineering, Makerere University, Kampala, Uganda \\ Email: tmibuulo22@gmail.com, kiggundu@caes.mak.ac.ug,banadda@caes.mak.ac.ug
}

How to cite this paper: Mibulo, T., Banadda, N. and Kiggundu, N. (2020) A Review of Packaging Options for Tomato Smallholder Farmers in Sub-Saharan Africa. Open Journal of Organic Polymer Materials, 10, 35-48.

https://doi.org/10.4236/ojopm.2020.104004

Received: October 6, 2020

Accepted: October 27, 2020

Published: October 30, 2020

Copyright $\odot 2020$ by author(s) and Scientific Research Publishing Inc. This work is licensed under the Creative Commons Attribution International License (CC BY 4.0).

http://creativecommons.org/licenses/by/4.0/

\begin{abstract}
Tomato production systems in developing countries are characterized by high post harvest losses. Due to the perishability of tomatoes, lack of awareness and knowledge of postharvest handling techniques, and poor packaging, farmers encounter $20 \%$ - 50\% postharvest losses. Farmers use traditional baskets, wooden, and plastic crates as packaging materials during transportation of tomatoes. However, tomatoes are often damaged due to the size and inner rough surface of crates and the difficulty in handling. The need for fresh tomato at the consumer requires a packaging that protects tomatoes against physical damages, increasing its shelf life prior to consumption. Packaging is important in ensuring quality, easing handling, extending the shelf life during storage and transportation of food products. However, the conventional use of synthetic-based materials for advanced packaging contributes to environmental problems because of their non-biodegradability and health concerns. This review article highlights the different materials used for packaging tomato and the prospects of using papaya, as a precursor for developing tomato packages.
\end{abstract}

\section{Keywords}

Packaging, Tomato, Biofilms, Sub-Saharan Africa, Papaya

\section{Introduction}

Tomato is second to potato among the world's most cultivated vegetables [1] [2] [3]. Currently, tomato is utilized as a commercial source of vitamins A and C, and antioxidants such as lycopene [4]. However, due to the perishability of tomatoes, lack of awareness and knowledge of postharvest handling techniques, and poor packaging, farmers encounter $20 \%-50 \%$ postharvest losses [5] [6]. Physical damages to tomatoes when transported to markets and distribution 
centers from farmers are the common post-harvest concern. Therefore, to obtain optimal shelf-life, it is essential to minimize physical damage to fresh produce. Reducing such post-harvest losses of vegetables can contribute substantially to improving food security of developing countries [7].

Packaging contributes to the vegetable's production value chain through providing protection, containment, marketing platform, convenience, and traceability [8]. All over the world, plastics usage in food packaging increases every day because of their diverse availability at relatively low costs. Also, the functional characteristics of plastic such as good optical properties, good tensile and tear strength, good permeability properties to oxygen and aroma compounds and heat seal ability favor its continual use [9] [10] [11]. The continuous plastic use, however, raises environmental and public health concerns since they are non-biodegradable [12] [13].

Plastics have been used for decades as packaging materials. However, scientists are making attempts to replace them with materials which are environmentally friendly [14] [15] [16] [17]. Biodegradable packaging materials which are environmentally friendly are generated from naturally occurring organic matter and can be generated from agricultural wastes contributing to bettering waste management [18] [19]. Packaging materials are colorless and flavorless by design, not to interfere with food chemical properties (sensory or nutritional appeal) [20]. Studies show that organic materials like papaya, mango, guava can be utilized to produce edible films that could be substituted as packaging material [14] [20] [21] [22]. According to [23], papaya puree has high pectin content which serves as a matrix to produce environmentally edible films. This paper therefore purposely critically explores the potential of using papaya as a packaging material for tomato.

\section{Tomato Production}

Solanum lycopersicum L., commonly known as cultivated tomato, is believed to originate from South American countries of Peru, Ecuador, and other parts of South America including the Galapagos Islands. Mexico is the center for domestication and scientific modification [24] [25], of the second most important, widely grown and consumed vegetable crop after potato [1] [2]. Due its numerous inherent nutrients, it contributes heavily to the human health [26]. It is a source of vitamin A, C, E, and lycopene, a red pigment serving as a natural antioxidant [27] [28] [29], calcium, water, and niacin, which are essential for metabolism.

Worldwide, tomato is grown for use locally or as an export commodity. Between 2010-2018, the Nigeria has been the leading producer of tomatoes on average annually in Sub-Saharan Africa (Table 1). In Uganda, production was on the rise from 2010 to 2017 but experienced a slight drop in 2018. Studies conducted on the tomato crop along different stages of production have improved its economic value [30] [31] [32] [33]. However, study efforts have been rooted 
Table 1. Tomato production in Sub-Saharan Africa.

\begin{tabular}{cccccccccc}
\hline $\begin{array}{c}\text { Production } \\
\text { (1000 tonnes) }\end{array}$ & $\mathbf{2 0 1 0}$ & $\mathbf{2 0 1 1}$ & $\mathbf{2 0 1 2}$ & $\mathbf{2 0 1 3}$ & $\mathbf{2 0 1 4}$ & $\mathbf{2 0 1 5}$ & $\mathbf{2 0 1 6}$ & $\mathbf{2 0 1 7}$ & $\mathbf{2 0 1 8}$ \\
\hline Ethiopia & 55.635 & 81.738 & 55.514 & 39.373 & 30.7 & 65.209 & 28.365 & 41.227 & 43.816 \\
Ghana & 318.52 & 320.5 & 321 & 340.218 & 366.772 & 366.772 & 366.772 & 368.915 & 381.015 \\
Kenya & 539.151 & 396.544 & 444.862 & 494.037 & 443.271 & 402.513 & 410.033 & 507.142 & 599.458 \\
Malawi & 112.606 & 120.605 & 40.5 & 265.054 & 526.07 & 523.041 & 483.74 & 450 & 583.177 \\
Nigeria & 1799.96 & 1491.319 & 2060.3 & 1925.12 & 4083.5 & 4229.33 & 3412.65 & 4100 & 3913.993 \\
Rwanda & 135 & 122.167 & 115 & 116.083 & 118.573 & 120.207 & 118.774 & 97.426 & 93.062 \\
Uganda & 31 & 30 & 35 & 34.953 & 36.24 & 38.002 & 39.406 & 40.979 & 39.462 \\
Tanzania & 300 & 350 & 390 & 423.323 & 387.774 & 400.366 & 403.821 & 359.786 & 356.094 \\
Zambia & 26 & 27 & 28.5 & 27.074 & 26.131 & 25.797 & 25.848 & 25.86 & 25.873 \\
Zimbabwe & 25 & 22.5 & 23.5 & 23.5 & 24.049 & 24.831 & 25.49 & 26.035 & 26.58 \\
\hline
\end{tabular}

Source: [38].

mainly concentrated on on-farm production related issues like pests and diseases leaving a gap on the tail end of the value chain, post-harvest making production vulnerable to losses [34]. Despite the high yields from the harvests, farmers encounter losses during post-harvest operations starting at harvest, post-harvest handling, packaging, transportation, and distribution. Post-harvest losses for fruits and vegetables range between $30 \%$ to $80 \%$ [35], the highest reaching $70 \%$ during storage and handling in the market places [36]. Losses increase during transportation of the produce from points of production to market centers [37].

\section{Packaging of Tomatoes}

Packaging simplifies the handling, transport, and distribution of products to the final consumers. Packaging of products provides a series of functions which include: protection/preservation, containment and waste reduction, marketing and information, traceability, convenience, tamper indication and many others [8] [39]. Therefore, employing appropriate packages, post-harvest losses in fruits and vegetables can be reduced. Packaging protects food like tomatoes from damages which are incurred from different sources (physical, chemical or biological) [40]. However, using unsuitable packaging normally results to fruit damage translating into losses along the food chain. Various packaging materials are used for commercial purpose for the sale of fresh produce at both retail and wholesale level. During storage and transport of fresh produce, the quality and shelf life is normally determined by the type and quality of packaging material.

\subsection{Traditional Baskets}

Traditional woven baskets made out of palm fronds and bamboo continue to dominate the handling of tomatoes within most developing countries' farmers [5] [41]. However, the use of the traditional baskets have cost both the small and large scale farmers at the local markets post-harvest losses ranging between $30 \%$ - 
$50 \%$ [42]. The losses result from excessive pressure to the fruits at the lower section resulting from packing [43] [44] [45]. Farmers minimize the physical damages on to the produce through making smooth lining of the basket's inner lining and lining up faster a cushioning layer of dry grass. However, the grass instead tends to interrupt with air movements hence increasing temperature which severally affects the tomatoes. Farmers are then recommended to use plastic crates which has holes for proper aeration.

\subsection{Wooden and Plastic Crates}

Wooden and plastic crates are the other materials dominating packaging and transport amongst farmers in developing countries, because they are cheap in making since they can be constructed from locally available materials [6] [41]. However, tomatoes are often damaged due to the size and inner rough surface of crates and the difficulty in handling [5]. To reduce the damages resulting from the impact in packaging crates during handling and transportation, packaging liners are used to serve as shock/impact absorbers. But, even with shock absorbers, the fruits damaged fruits remain high, ranging from $20 \%-50 \%$ [46]. The damage can relatively be reduced to below $40 \%$ with plastic-lined baskets; however, the cost of buying plastics is high, limiting their use. In Nigeria, a participatory development approach on addressing post-harvest losses along the value chain of tomatoes was conducted in 2018 with local small-scale farmers. At the end of the case study, $89 \%$ of participants bought plastic crates to replace traditional baskets for transporting tomatoes after discovering that the latter causes higher losses [47]. In South Africa plastic crates and cartons are adopted for use in open-air markets for marketing tomatoes by small-scale growers and retailers [48].

\subsection{Plastic Films}

Food packaging for market sales is an important aspect of food distribution. The material type selected to design a package normally determines market value quality of tomato [49]. Polyethylene (PE) and polypropylene (PP), because of their low water permeability properties, are highly preferred plastic films for packaging [11] [23] [50]. In the plastic film application study, fully ripe tomato fruits were stored for 8,15 , and 22 days at temperatures of $20^{\circ} \mathrm{C}$ and $95 \%$ relative humidity using polyethylene film, perforated polyethylene film, cellophane, and perforated cellophane. The packaging did not affect the color and overall acceptability, however, there was a significant weight loss ( $>0.1 \mathrm{~g} /$ day) for perforated film packaged tomatoes because of the undisturbed evaporation process [51]. The physiological weight loss for non-perforated polyethylene bags was $0.29 \%$ at three days and $1.72 \%$ at 6 days of storage. After the storage period, $24.57 \%$ of the perforated polythene bags experienced physiological weight loss. Non-perforated polyethylene had a $60 \%$ decay loss of tomato fruits higher than the perforated ones after the storage period. 
Plastic films are used in the Modified Atmosphere Packaging (MAP) process. MAP is technique using the predetermined composition of respiratory gases (oxygen $\left(\mathrm{O}_{2}\right)$ and carbon dioxide $\left(\mathrm{CO}_{2}\right)$ ) gases appropriate to preserve the produce for a specified period of time [52]. MAP packaging materials primarily function to create a permeation barrier for the gases until a stable equilibrium is reached between the external gases and those inside the package [53]. The MAP packaging materials commonly used include; polyethylene terephthalate (PET), low-density polyethylene (LDPE), high-density polyethylene (HDPE), polyvinyl chloride (PVC), polypropylene, polystyrene [54] [55], and some chemically modified derivatives.

[56] compared different plastic packaging materials for their effects on the quality attributes of tomatoes during cold storage and after a shelf life period. Perforated (0.4\%) low-density polyethylene (LDPE), sealed low-density polyethylene (LDPE) and sealed stretch bags were used for storing tomatoes for five weeks at $10^{\circ} \mathrm{C} \pm 1{ }^{\circ} \mathrm{C}$ and $90 \%-95 \%$ relative humidity. During both cold storage and shelf-life periods, all the packaging materials performed better in preserving the fruit's firmness and vitamin C. However, fruit weight losses, fruits decay, Total Soluble Solids (TSS), and lycopene during both storage periods were significantly affected.

Tomatoes are pretreated with chemicals for preventing deterioration during transportation and storage periods. [57] used $70 \%$ ethanol and $0.2 \%$ benomyl for pretreating tomatoes before packaging in low-density polyethylene, high-density polyethylene, and raffia palm basket stored at $27^{\circ} \mathrm{C}-32^{\circ} \mathrm{C}$ for up to 16 days. Benomyl-treated fruits in low-density polyethylene retained the highest total soluble solids (TSS) compared to other treatments. Fruits treated with benomyl had the lowest microbial load, however, fruit spoilage increased with storage time for all treatments. Hot water when used as a pretreatment helped in maintaining color, firmness, total soluble solids and beta-carotene [58].

\subsection{Edible Coatings and Films}

Edible films and coatings are thin layers of material with thickness generally less than $0.3 \mathrm{~mm}$ casted on food products to substitute or/and fortify the food's outer layer for which can be eaten as a part of the product [59]. They are applied to foods either by first producing them separately and utilized as a wrap or immersion of the food product in to the suspension or spraying/drenching (coating) of the suspension to the food produce [60] [61]. Edible films and coatings serve as a diffusion barrier which selectively allows exchange of moisture, carbon dioxide, oxygen, and ethylene. The two terms are used synonymously, however, a coating is applied in a liquid form, usually by dipping the product in solution of the edible material, while the film is pre-manufactured before application [52] [59].

Way back in the 12th centuries, Chinese applied wax applied on oranges and lemons as edible films and coating for preservation of moisture and aesthetics during transportation [59]. The Japanese boiled and air-dried soymilk protein to 
produce "Yuba" film as their first edible film during the 15th century. Fats were used in prevent loss of moisture from meat in the process called "larding" during 16th century, in the United Kingdom [62]. The increasing cost and competition for petroleum, the structural materials of the synthetic packaging materials has promoted the utilization of the cheaply available materials [63]. The increasing demands for fresh and fresh foods also attract the promotion of investing in biodegradable packages.

Since the advent of edible films and coatings, several studies have been carried out. [64] evaluated the quality attributes of cherry tomatoes packaged with edible films produced from varying ratios of yam starch and glycerol. The sanitized cleaned tomatoes were immersed in suspensions of yam starch and glycerol and kept in a controlled environment of $25^{\circ} \mathrm{C}$ and $70 \%$ relative humidity, for 18 days. A composite coating of 7.5\% yam starch and 30\% glycerol proportions retained higher stability for the loss in mass, antioxidant activity, and lycopene content relative to the freshly harvested fruit. Chitosan films were used by [65] to study the storage behaviors of tomatoes. Respiration studies showed that $1 \%$ of chitosan treatments created a more balanced environment in terms of respiratory gases, $\mathrm{CO}_{2}$ and $\mathrm{O}_{2}$. Corn-zein film coatings are also other protein-based edible packaging film. Corn-zein coatings with 5 and $15 \mu \mathrm{m}$ thickness delayed the ripening of tomatoes by 6 -days without adverse effects and the $66 \mu \mathrm{m}$ coating distinctly delayed color development and due to anaerobic fermentation, there was high weight loss [66]. A composite edible coating consisting of Soy Protein Isolate (90\% protein), Glycerol (plasticizer) and Carboxymethyl Cellulose, Oleic Acid, Sodium Benzoate and Ascorbic Acid resulted in to a significant effect on titratable acidity, vitamin C content, TSS and total and reducing sugars after the storage of nine days, except the $\mathrm{pH}$ for coated samples as compared to the control sample after nine days of storage [67].

\subsection{Papaya as a Packaging Material}

Biodegradable/edible coatings and films are categorized according to their structural building material. Proteins, lipids, and polysaccharides are the major structural components however, due to natural abundance and low toxicity, polysaccharides are the highly utilized [52] [68] [69]. Starch, cellulose, pectin, chitosan, alginate, agar, and carrageenan are the main polysaccharide materials utilized in edible packaging materials [15] [70] [71] [72]. Research is currently concentrated on developing composite or multicomponent films and coatings to help improve the functional characteristics of individual components contributing to the composite product [14] [73] [74].

Papaya is among the widely grown fruit in Uganda. In 2017, the fruit contribution to exports in terms of mass was about 5200 tones [75]. It was observed that, the fruit experiences about $75 \%$ losses after harvesting [76], however, the waste can be utilized [77] [78]. Papaya consists of various biopolymer components which can be used to develop composite films and coatings. Cellulose is a 
linear, high molecular weight polymer and a biodegradable material can be extracted from papaya peels for making edible packages [79]. It has strong inter and intra molecular hydrogen bonds rendering it high strength making them hard to melt and dissolving in common solvents [80]. Therefore, utilizing cellulose in food applications, it is converted first into its derivatives. Carboxymethyl cellulose, the most common derivative is a linear, long-chain, water-soluble, anionic polysaccharide [81]. When purified, it has a white to cream color, tasteless, odorless, and free flowing. It is reported to be applied in biodegradable films [82] [83].

Papaya is also a potential source of pectin, another material used in the manufacture of edible films [84]. Pectin is a gelatin-like polymer with high molecular weight found in the middle lamella of plant cells, contributing to their structure [21] [85]. Pectin extracted from papaya puree blended with gelatin, and defatted soy protein produced packaging films/coatings which exhibited good mechanical, barrier, and optical properties [14]. Biodegradable films based on gelatin and papaya peel showed high antioxidant activity which is a key attribute for packaging [16].

Papaya exhibits excellent packaging attributes compared to other fruit packaging materials. Papaya has high tensile strength ranging between $20-30 \mathrm{MPa}$ when hydroxypropyl methylcellulose is used as a binding agent [21]. Apple follows with 9 - $20 \mathrm{MPa}$ using carboxymethylcellulos, gellatin, methylcellulose and poly lactic acid as binding agents [86]. Also, tomato packaging materials with high methoxyl pectin binding agent exhibit 8.9 - 14.8 MPa of tensile strength [87]. In terms of water vapour permeability, papaya has low values $(2.15-3.16$ $\left.\mathrm{m}^{2} / \mathrm{h} / \mathrm{kPa}\right)$ [21]. However, they are improved $\left(5.55-8.45 \mathrm{~m}^{2} / \mathrm{h} / \mathrm{kPa}\right)$ when blended with starch, soya proteins and gellatin [14]. Compared with others, apples have good water vapour permeability $(5.84-13.57 \mathrm{~m} / \mathrm{h} / \mathrm{kPa})$ [88] [89]. Papaya puree films have low oxygen permeability $\left(7.5 \mathrm{~cm}^{3} \mu \mathrm{m} / \mathrm{m}^{2} / \mathrm{d} / \mathrm{kPa}\right)$ [14] compared to apple puree films $\left(83.6 \mathrm{~cm}^{3} \mu \mathrm{m} / \mathrm{m}^{2} / \mathrm{d} / \mathrm{kPa}\right)$ [87]. However, all these values are remarkably smaller than conventional films from $\operatorname{HDPE}\left(427 \mathrm{~cm}^{3} \mu \mathrm{m} / \mathrm{m}^{2} / \mathrm{d} / \mathrm{kPa}\right)$ and LDPE $\left(1870 \mathrm{~cm}^{3} \mu \mathrm{m} / \mathrm{m}^{2} / \mathrm{d} / \mathrm{kPa}\right)$ - measured at $23^{\circ} \mathrm{C}$ and $50 \% \mathrm{RH}$ [88].

Papaya also has a wide range of medicinal and nutritional properties [90]. Cancer cells are significantly reduced when pectin collected at different stages of papaya ripening are applied [78]. Therefore, incorporating papaya in the composite biodegradable edible composite packaging films and coatings is a great prospect both to the environment and human life.

\section{Conclusion}

This study reviewed the different means for packaging tomatoes and the prospects of using papaya-based materials. Synthetics have been used to produce tomato packaging materials; however, due to environmental and health concerns they need a substitute. Biodegradable edible packaging films and coatings have the potential for replacing conventional synthetic materials. However, using sin- 
gle structural components for developing these materials results in some properties not appropriate. Therefore, the use of different sources of structural material to form composite films and coating is needed. Papaya has good potential if blended with other biopolymers to edible films and coatings. Papaya has both high percentages of pectin and cellulose which are the major building materials for biodegradable packaging materials.

\section{Conflicts of Interest}

The authors declare no conflict of interest.

\section{References}

[1] Hammond, R.W. (2017) Chap. 1. Economic Significance of Viroids in Vegetable and Field Crops. In: Hadidi, A., Flores, R., Palukaitis, P. and Randles, J. Eds., Viroids and Satellites, Academic Press, Cambridge, MA,, 5-13. https://doi.org/10.1016/B978-0-12-801498-1.00001-2

[2] Singh, K.V., Singh, A.K. and Kumar, A. (2017) Disease Management of Tomato through PGPB: Current Trends and Future Perspective. 3 Biotech, 7, Article No. 255. https://doi.org/10.1007/s13205-017-0896-1

[3] de Vos, R.C.H., Hall, D.R. and Moing, A. (2011) Metabolomics of a Model Fruit: Tomato. In: Hall, D.R., Ed., Annual Plant Reviews Volume 43: Biology of Plant Metabolomics, Blackwell Publishing Ltd., Hoboken, NJ, 109-155. https://doi.org/10.1002/9781444339956.ch5

[4] Okolie, N.P. and Sannie, T.E. (2012) Effect of Post Harvest Treatments on Quality of Whole Tomatoes. African Journal of Food Science, 6, 70-76.

[5] Kitinoja, L. and Kader, A.A. (2015) Measuring Postharvest Losses of Fresh Fruits and Vegetables in Developing Countries. The Postharvest Education Foundation Paper 15-02. http://postharvest.org/PEF_White_Paper_15-02_PHFVmeasurement.pdf

[6] Emana, B., Afari-Sefa, V., Nenguwo, N., Ayana, A., Kebede, D. and Mohammed, H. (2017) Characterization of Pre- and Postharvest Losses of Tomato Supply Chain in Ethiopia. Agriculture and Food Security, 6, Article No. 3. https://doi.org/10.1186/s40066-016-0085-1

[7] Affognon, H., Mutungi, C., Sanginga, P. and Borgemeister, C. (2015) Unpacking Postharvest Losses in Sub-Saharan Africa: A Meta-Analysis. World Development, 66, 49-68. https://doi.org/10.1016/j.worlddev.2014.08.002

[8] Marsh, K. and Bugusu, B. (2007) Food Packaging-Roles, Materials, and Environmental Issues: Scientific Status Summary. Journal of Food Science, 72, R39-R55. https://doi.org/10.1111/j.1750-3841.2007.00301.x

[9] Osborn, K.R. and Jenkins, W.A. (1992) Plastic Films: Technology and Packaging Applications. Technomic Publishing Company Inc., Lancaster, PA.

[10] Piringer, O. and Baner, A. (2000) Plastic Packaging Materials for Food Barrier Function, MassTransport, Quality Assurance and Legislation. Wiley-VCH, Weinheim, Germany. https://doi.org/10.1002/9783527613281

[11] Sharma, C., Manepalli, P.H., Thatte, A., Thomas, S., Kalarikkal, N. and Alavi, S. (2017) Biodegradable Starch/PVOH/Laponite RD-Based Bionanocomposite Films Coated with Graphene Oxide: Preparation and Performance Characterization for Food Packaging Applications. Colloid and Polymer Science, 295, 1695-1708. 
https://doi.org/10.1007/s00396-017-4114-9

[12] Owusu, P.A., Banadda, N. and Kiggundu, N. (2017) Mass Balance of Plastic Waste Conversion to Fuel Oil-A case in Uganda. Journal of Sustainable Development, 10, 41-50. https://doi.org/10.5539/jsd.v10n6p41

[13] Leal Filho, W., Saari, U., Fedoruk, M., Iital, A., Moora, H., Klöga, M. and Voronova, V. (2019) An Overview of the Problems Posed by Plastic Products and the Role of Extended Producer Responsibility in Europe. Journal of Cleaner Production, 214, 550-558. https://doi.org/10.1016/j.jclepro.2018.12.256

[14] Tulamandi, S., Rangarajan, V., Rizvi, S.S.H., Singhal, R.S., Chattopadhyay, S. and Saha, N. (2016) A Biodegradable and Edible Packaging Film Based on Papaya Puree, Gelatin, and Defatted Soy Protein. Food Packaging and Shelf Life, 10, 60-71.

https://doi.org/10.1016/j.fpsl.2016.10.007

[15] Ramos, M., Valdés, A., Beltrán, A. and Garrigós, M. (2016) Gelatin-Based Films and Coatings for Food Packaging Applications. Coatings, 6, 41. https://doi.org/10.3390/coatings6040041

[16] de Moraes Crizel, T., de Oliveira Rios, A., Alves, V.D., Bandarra, N., Moldão-Martins, M. and Hickmann Flôres, S. (2018) Biodegradable Films Based on Gelatin and Papaya Peel Microparticles with Antioxidant Properties. Food and Bioprocess Technology, 11, 536-550. https://doi.org/10.1007/s11947-017-2030-0

[17] Otoni, C.G., Avena-Bustillos, R.J., Azeredo, H.M.C., Lorevice, M.V., Moura, M.R., Mattoso, L.H.C. and McHugh, T.H. (2017) Recent Advances on Edible Films Based on Fruits and Vegetables-A Review. Comprehensive Reviews in Food Science and Food Safety, 16, 1151-1169. https://doi.org/10.1111/1541-4337.12281

[18] González, A., Strumia, M.C. and Igarzabal, C.I.A. (2011) Cross-Linked Soy Protein as Material for Biodegradable Films: Synthesis, Characterization and Biodegradation. Journal of Food Engineering, 106, 331-338. https://doi.org/10.1016/j.jfoodeng.2011.05.030

[19] Arancibia, M.Y., López-Caballero, M.E., Gómez-Guillén, M.C. and Montero, P. (2014) Release of Volatile Compounds and Biodegradability of Active Soy Protein Lignin Blend Films with Added Citronella Essential Oil. Food Control, 44, 7-15. https://doi.org/10.1016/j.foodcont.2014.03.025

[20] Viana, M.R., Sá, N.M.S.M., Barros, M.O., Borges, M.D.F. and Azeredo, H.M.C. (2018) Nanofibrillated Bacterial Cellulose and Pectin Edible Films Added with Fruit Purees. Carbohydrate Polymers, 196, 27-32. https://doi.org/10.1016/j.carbpol.2018.05.017

[21] Otoni, C.G., de Moura, M. R., Aouada, F.A., Camilloto, G.P., Cruz, R.S., Lorevice, M.V., Soares, N.F. and Mattoso, L.H.C. (2014) Antimicrobial and Physical-Mechanical Properties of Pectin/Papaya Puree/Cinnamaldehyde Nanoemulsion Edible Composite Films. Food Hydrocolloids, 41, 188-194.

https://doi.org/10.1016/j.foodhyd.2014.04.013

[22] Azeredo, H.M.C., Morrugares-Carmona, R., Wellner, N., Cross, K., Bajka, B. and Waldron, K.W. (2016) Development of Pectin Films with Pomegranate Juice and Citric Acid. Food Chemistry, 198, 101-106.

https://doi.org/10.1016/j.foodchem.2015.10.117

[23] Tharanathan, R.N. (2003) Biodegradable Films and Composite Coatings: Past, present and future. Trends in Food Science and Technology, 14, 71-78. https://doi.org/10.1016/S0924-2244(02)00280-7

[24] Jenkins, J.A. (1984) The Origin of the Cultivated Tomato. Economic Botany, 2, 379-392. https://doi.org/10.1007/BF02859492 
[25] Peralta, I.E. and Spooner, D.M. (2007) History, Origin, and Early Cultivation of Tomato. In: Razdan, M. and Mattoo, A., Eds., Genetic Improvement of Solanaceous Crops, Science Publishers, Enfield, New Hampshire, USA, 1-24.

[26] Rao, A.V., Waseem, Z. and Agarwal, S. (1998) Lycopene Content of Tomatoes and Tomato Products and Their Contribution to Dietary Lycopene. Food Research International, 31, 737-741. https://doi.org/10.1016/S0963-9969(99)00053-8

[27] Shi, J. and Le Maguer, M. (2000) Lycopene in Tomatoes: Chemical and Physical Properties Affected by Food Processing. Critical Reviews in Food Science and Nutrition, 40, 1-42. https://doi.org/10.1080/10408690091189275

[28] Kabwama, S.N., Bahendeka, S.K., Wesonga, R., Mutungi, G. and Guwatudde, D. (2019) Low Consumption of Fruits and Vegetables among Adults in Uganda: Findings from a Countrywide Cross-Sectional Survey. Archives of Public Health, 77, 4-11. https://doi.org/10.1186/s13690-019-0332-6

[29] Kalantar-Zadeh, K. and Moore, L.W. (2020) Impact of Nutrition and Diet on COVID-19 Infection and Implications for Kidney Health and Kidney Disease Management. Journal of Renal Nutrition, 30, 179-181. https://doi.org/10.1053/j.jrn.2020.03.006

[30] Ochilo, W.N., Nyamasyo, G.N., Kilalo, D., Otieno, W., Otipa, M., Chege, F., Karanja, T. and Lingeera, E.K. (2019) Characteristics and Production Constraints of Smallholder Tomato Production in Kenya. Scientific African, 2, e00014. https://doi.org/10.1016/j.sciaf.2018.e00014

[31] Bwire, D., Watanabe, F., Suzuki, S. and Kuga, S. (2018) Optimal Water Use on Low Pressure Drip Irrigation System for Tomato Cultivation in Uganda. Journal of Arid Land Studies, 28, 77-80.

[32] Karuku, G.N., Kimenju, J.W. and Verplancke, H. (2017) Farmers' Perspectives on Factors Limiting Tomato Production and Yields in Kabete, Kiambu County, Kenya. East African Agricultural and Forestry Journal, 82, 70-89. https://doi.org/10.1080/00128325.2016.1261986

[33] Bett, E., Mugwe, J., Nyalugwe, N., Haraman, E., Williams, F., Tambo, J. and Bundi, M. (2018) Impact of Plant Clinics on Disease and Pest Management, Tomato Productivity and Profitability in Malawi. CABI Working Paper 11.

[34] Wakholi, C., Cho, B.-K., Mo, C. and Kim, M.S. (2015) Current State of Postharvest Fruit and Vegetable Management in East Africa. Journal of Biosystems Engineering, 40, 238-249. https://doi.org/10.5307/JBE.2015.40.3.238

[35] ACET (2014) The Fruit Value Capture Opportunity in Africa. Pathways to Transformation.

http://acetforafrica.org/acet/wp-content/uploads/publications/2016/03/Fruit-Dalber g.pdf

[36] Kimaro, E. and Msogya, T. (2012) Postharvest Losses of Mangro Fruit (Mangifera indica) in Morogoro Region. Proceedings of the RUFORUM 3rd Biennial Conference, Entebbe, Uganda, 24-28 September 2012, 799-803.

[37] Kehlenbeck, K., Asaah, E. and Jamnadass, R. (2013) Diversity of Indigenous Fruit Trees and Their Contribution to Nutrition and Livelihoods in Sub-Saharan Africa: Examples from Kenya and Cameroon. In: Fanzo, J., Hunter, D., Borelli, T. and Mattei, F., Eds., Diversifying Food and Diets: Using Agricultural Biodiversity to Improve Nutrition and Health, Routledge, London and New York, 257-269.

[38] FAOSTAT (2020) Food and Agricultural Organization of the United Nations. http://www.fao.org/faostat/en/\#data

[39] Coles, R., McDowell, D. and Kirwan, M. (2003) Food Packaging Technology. 
Blackwell Publishing, Oxford, UK.

[40] Prasad, P. and Kochhar, A. (2014) Active Packaging in Food Industry: A Review. IOSR Journal of Environmental Science, Toxicology and Food Technology, 8, 1-7. https://doi.org/10.9790/2402-08530107

[41] Kereth, G., Lyimo, M., Mbwana, H., Mongi, R.J. and Ruhembe, C.C. (2013) Assessment of Post-harvest Handling Practices: Knowledge and Losses of Fruits in Bagamoyo District of Tanzania. Journal of Food Science and Quality Management, 11, 8-16.

[42] Kangire, A., Musana, S., Asea, G., Otim, A., Aisu, G., Logose, M. and Kashaija, I. (2016) A guide to Effective Harvesting, Hanadling and Quality Marketing of Tomato in Uganda. In: Postharvest Handling of Tomato in Africa, National Institute of Horticultural and Herbal Science, Rural Development Administration, Korea, 55-68.

[43] Aba, I.P., Gana, Y.M., Ogbonnaya, C. and Morenikeji, O.O. (2012) Simulated Transport Damage Study on Fresh Tomato (Lycopersicon esculentum) Fruits. Agricultural Engineering International: CIGR Journal, 14, 119-126.

[44] Kitinoja, L. and AlHassan, H.Y. (2012) Identification of Appropriate Postharvest Technologies for Small Scale Horticultural Farmers and Marketers in Sub-Saharan Africa and South Asia-Part 1. Postharvest Losses and Quality Assessments. Acta Horticulturae, 934, 31-40. https://doi.org/10.17660/ActaHortic.2012.934.1

[45] Ugonna, C., Jolaoso, M. and Onwualu, A. (2015) Tomato Value Chain in Nigeria: Issues, Challenges and Strategies. Journal of Scientific Research and Reports, 7, 501-515. https://doi.org/10.9734/JSRR/2015/16921

[46] Dari, L., Nenguwo, N. and Afari-Sefa, V. (2018) Evaluation of Packaging Liners in Wooden and Plastic Crates for Handling Tomatoes. Journal of Postharvest Technology, 6, 36-40.

[47] Plaisier, C., Sibomana, M., van der Waal, J., Clercx, L., van Wagenberg, C.P.A. and Dijkxhoorn, Y. (2019) Approach for Designing Context-Specific, Locally Owned Interventions to Reduce Postharvest Losses: Case Study on Tomato Value Chains in Nigeria. Sustainability, 11, 247. https://doi.org/10.3390/su11010247

[48] Mashau, M., Moyane, J. and Jideani, I.A. (2012) Assessment of Post Harvest Losses of Fruits at Tshakhuma Fruit Market in Limpopo Province, South Africa. African Journal of Agricultural Research, 7, 4145-4150.

[49] Radusin, T.I., Kevrešan, T,.S., Mastilović, J.S., Novaković, A.R. and Hajnal, E.P.J. (2013) Influence of Different Packaging Solutions on Qualitative and Quantitative Properties of Fresh Tomato Variety Izmir during Storage at Market Conditions. Food and Feed Research, 40, 85-92.

[50] Kirwan, M.J., Plant, S. and Strawbridge, J.W. (2011) Plastics in Food Packaging. In: Coles, R. and Kirwan, M., Eds., Food and Beverage Packaging Technology, Blackwell Publishing Ltd., Hoboken, NJ, 157-212. https://doi.org/10.1002/9781444392180.ch7

[51] Ashenafi, H. (2018) Shelf Life and Quality of Tomato (Lycopersicon esculentum Mill.) Fruits as Affected by Different Packaging Materials. African Journal of Food Science, 12, 21-27. https://doi.org/10.5897/AJFS2017.1568

[52] Falguera, V., Quintero, J.P., Jiménez, A., Muñoz, J.A. and Ibarz, A. (2011) Edible Films and Coatings: Structures, Active Functions and Trends in Their Use. Trends in Food Science and Technology, 22, 292-303. https://doi.org/10.1016/j.tifs.2011.02.004 
[53] Yildirim, S., Röcker, B., Pettersen, M. K., Nilsen-Nygaard, J., Ayhan, Z., Rutkaite, R., Radusin, T., Suminska, P., Marcos, B. and Coma, V. (2018) Active Packaging Applications for Food. Comprehensive Reviews in Food Science and Food Safety, 17, 165-199. https://doi.org/10.1111/1541-4337.12322

[54] Kader, A.A., Zagory, D. and Kerbel, E. (1989) Modified Atmosphere Packaging for Fruits and Vegetables. Critical Reviews in Food Science and Nutrition, 28, 1-30. https://doi.org/10.1080/10408398909527490

[55] Exama, A., Arul, J., Lencki, R.W., Lee, L.Z. and Toupin, C. (1993) Suitability of Plastic Films for Modified Atmosphere Packaging of Fruits and Vegetables. Journal of Food Science, 58, 1365-1370. https://doi.org/10.1111/j.1365-2621.1993.tb06184.x

[56] Asem, A., Hassan, S.A., Arisha, H.M.E., Bardisi, A.A. and Sabreen, K.A.I. (2017) Effect of Some Packaging Materials on Quality Attributes of Tomato Fruits (Solanum lycopersicum L.) during Cold Storage and after Shelf Life Period. Middle East Journal of Agriculture Research, 5, 687-700.

[57] Efiuvwevwere, B.J.O. and Uwanogho, G.U. (1990) Effects of Packaging Materials Following Ethanol and Benomyl Treatments on Chemical and Microbiological Changes in Tomato (Lycopersicon esculentum) Fruits. Journal of the Science of Food and Agriculture, 52, 393-402. https://doi.org/10.1002/jsfa.2740520312

[58] Akbudak, B., Akbudak, N., Seniz, V. and Eris, A. (2007) Sequential Treatments of Hot Water and Modified Atmosphere Packaging in Cherry Tomatoes. Journal of Food Quality, 30, 896-910. https://doi.org/10.1111/j.1745-4557.2007.00168.x

[59] Paviath, A.E. and Orts, W. (2009) Edible Films and Coatings: Why, What, and How? In: Milda, E.E. and Huber, K.C., Eds., Edible Films and Coatings for Food Applications, Springer, New York, 1-23.

https://doi.org/10.1007/978-0-387-92824-1_1

[60] Milani, J.M. and Tirgarian, B. (2020) An Overview of Edible Protein-Based Packaging: Main Sources, Advantages, Drawbacks, Recent Progressions and Food Applications. Journal of Packaging Technology and Research, 4, 103-115. https://doi.org/10.1007/s41783-020-00086-w

[61] Galus, S. and Kadzińska, J. (2015) Food Applications of Emulsion-Based Edible Films and Coatings. Trends in Food Science and Technology, 45, 273-283. https://doi.org/10.1016/j.tifs.2015.07.011

[62] Labuza, T.P. and Contreras-Medellin, R. (1981) Prediction of Moisture Protection Requirements for Foods. Cereal Foods World, 26, 335-343.

[63] Dangaran, K., Tomasula, P.M. and Qi, P. (2009) Structure and Function of Protein-Based Edible Films and Coatings. In: Embuscado, M.E. and Huber, K.C., Eds., Edible Films and Coatings for Food Applications, Springer, New York, 25-56. https://doi.org/10.1007/978-0-387-92824-1_2

[64] Reis, R.C., dos, Devilla, I.A., Correa, P.C., de Oliveira, G.H.H. and Castro, V. (2015) Postharvest Conservation of Cherry Tomato with Edible Coating. African Journal of Agricultural Research, 10, 1164-1170.

[65] Thumula, P. (2006) Studies on Storage Behaviour of Tomatoes Coated with Chitosan-Lysozyme Films. Doctoral Dissertation, McGill University, Montréal, QC.

[66] Park, H.J., Chinnan, M.S. and Shewfelt, R.L. (1994) Edible Corn-Zein Film Coatings to Extend Storage Life of Tomatoes. Journal of Food Processing and Preservation, 18, 317-331. https://doi.org/10.1111/j.1745-4549.1994.tb00255.x

[67] Nandane, A.S. and Jain, R.K. (2011) Effect of Composite Edible Coating on Physicochemical Properties of Tomatoes Stored at Ambient Conditions. International 
Journal of Advanced Engineering Technology, 2, 211-217.

[68] Crouzier, T., Boudou, T. and Picart, C. (2010) Polysaccharide-Based Polyelectrolyte Multilayers. Current Opinion in Colloid and Interface Science, 15, 417-426. https://doi.org/10.1016/j.cocis.2010.05.007

[69] Milkova, V. and Radeva, T. (2015) Influence of Charge Density and Calcium Salt on Stiffness of Polysaccharides Multilayer Film. Colloids and Surfaces A: Physicochemical and Engineering Aspects, 481, 13-19. https://doi.org/10.1016/j.colsurfa.2015.03.061

[70] Espitia, P.J.P., Du, W.X., Avena-Bustillos, R.J., Soares, N.F.F. and McHugh, T.H. (2014) Edible Films from Pectin: Physical-Mechanical and Antimicrobial Properties-A Review. Food Hydrocolloids, 35, 287-296.

https://doi.org/10.1016/j.foodhyd.2013.06.005

[71] Homez-Jara, A., Daza, L.D., Aguirre, D.M., Muñoz, J.A., Solanilla, J.F. and Váquiro, H.A. (2018) Characterization of Chitosan Edible Films Obtained with Various Polymer Concentrations and Drying Temperatures. International Journal of Biological Macromolecules, 113, 1233-1240. https://doi.org/10.1016/j.ijbiomac.2018.03.057

[72] Wang, X., Guo, C., Hao, W., Ullah, N., Chen, L., Li, Z. and Feng, X. (2018) Development and Characterization of Agar-Based Edible Films Reinforced with $\mathrm{Na}$ no-Bacterial Cellulose. International Journal of Biological Macromolecules, 118, 722-730. https://doi.org/10.1016/j.ijbiomac.2018.06.089

[73] Galus, S., Lenart, A., Voilley, A. and Debeaufort, F. (2013) Effect of Oxidized Potato Starch on the Physicochemical Properties of Soy Protein Isolate-Based Edible Films. Food Technology and Biotechnology, 51, 403-409.

[74] Kurek, M., Galus, S. and Debeaufort, F. (2014) Surface, Mechanical and Barrier Properties of Bio-Based Composite Films Based on Chitosan and Whey Protein. Food Packaging and Shelf Life, 1, 56-67. https://doi.org/10.1016/j.fpsl.2014.01.001

[75] Dijkxhoorn, Y., van Galen, M., Barungi, J., Okiira, J., Gema, J. and Janssen, V. (2019) The Uganda Vegetables and Fruit Sector: Competitiveness, Investment and Trade Options. Wageningen Economic Research, Wageningen. https://doi.org/10.18174/505785

[76] Paull, R.E., Nishijima, W., Reyes, M. and Cavaletto, C. (1997) Postharvest Handling and Losses during Marketing of Papaya (Carica papaya L.). Postharvest Biology and Technology, 11, 165-179. https://doi.org/10.1016/S0925-5214(97)00028-8

[77] Maran, J.P. and Prakash, K.A. (2015) Process Variables Influence on Microwave Assisted Extraction of Pectin from Waste Carcia papaya L. Peel. International Journal of Biological Macromolecules, 73, 202-206.

https://doi.org/10.1016/j.ijbiomac.2014.11.008

[78] Do Prado, S.B.R., Ferreira, G.F., Harazono, Y., Shiga, T.M., Raz, A., Carpita, N.C. and Fabi, J.P. (2017) Ripening-Induced Chemical Modifications of Papaya Pectin Inhibit Cancer Cell Proliferation. Scientific Reports, 7, Article No. 16564. https://doi.org/10.1038/s41598-017-16709-3

[79] Rachtanapun, P. (2009) Blended Films of Carboxymethyl Cellulose from Papaya Peel (CMCp) and Corn Starch. Kasetsart Journal: Natural Science, 43, 259-266.

[80] Hattori, K., Abe, E., Yoshida, T. and Cuculo, J.A. (2004) New Solvents for Cellulose. II. Ethylenediamine/Thiocyanate Salt System. Polymer Journal, 36, 123-130. https://doi.org/10.1295/polymj.36.123

[81] Cagri, A., Ustunol, Z. and Ryser, E.T. (2002) Inhibition of Three Pathogens on Bologna and Summer Sausage Using Antimicrobial Edible Films. Journal of Food 
Science, 67, 2317-2324. https://doi.org/10.1111/j.1365-2621.2002.tb09547.x

[82] Rachtanapun, P., Kumthai, S., Yakee, N. and Uthaiyod, R. (2007) Production of Carboxymethylcellulose (CMC) Film from Papaya Peels and Its Mechanical Properties. Proceedings of the Annual Conference of the Kasetsart University, Bangkok, Thailand, 30 January-2 February 2007, 790-799.

[83] Almasi, H., Ghanbarzadeh, B. and Entezami, A.A. (2010) Physicochemical Properties of Starch-CMC-Nanoclay Biodegradable Films. International Journal of Biological Macromolecules, 46, 1-5. https://doi.org/10.1016/j.ijbiomac.2009.10.001

[84] Westerlund, E., Åman, P., Andersson, R., Andersson, R.E. and Rahman, S.M.M. (1991) Chemical Characterization of Water-Soluble Pectin in Papaya Fruit. Carbohydrate Polymers, 15, 67-78. https://doi.org/10.1016/0144-8617(91)90020-D

[85] da Rocha, M., de Souza, M.M. and Prentice, C. (2018) Biodegradable Films: An Alternative Food Packaging. In: Grumezescu, A.M. and Holban, A.M., Eds., Food Packaging and Preservation, Academic Press, Cambridge, MA, 307-342. https://doi.org/10.1016/B978-0-12-811516-9.00009-9

[86] Eca, K.S., Machado, M.T.C., Hubinger, M.D. and Menegalli, F.C. (2015) Development of Active Films from Pectin and Fruit Extracts: Light Protection, Antioxidant Capacity, and Compounds Stability. Journal of Food Science, 80, C2389-C2396. https://doi.org/10.1111/1750-3841.13074

[87] Du, W.-X., Olsen, C.W., Avena-Bustillos, R.J., McHugh, T.H., Levin, C.E. and Friedman, M. (2008) Antibacterial Activity against E. coli O157:H7, physical Properties, and Storage Stability of Novel Carvacrol-Containing Edible Tomato Films. Journal of Food Science, 73, M378-M383. https://doi.org/10.1111/j.1750-3841.2008.00892.x

[88] McHugh, T.H., Huxsoll, C.C. and Krochta, J.M. (1996) Permeability Properties of Fruit Puree Edible Films. Journal of Food Science, 61, 88-91. https://doi.org/10.1111/j.1365-2621.1996.tb14732.x

[89] McHugh, T.H. and Senesi, E. (2000) Apple Wraps: A Novel Method to Improve the Quality and Extend the Shelf Life of Fresh-Cut Apples. Journal of Food Science, 65, 480-485. https://doi.org/10.1111/j.1365-2621.2000.tb16032.x

[90] Vij, T. and Prashar, Y. (2015) A Review on Medicinal Properties of Carica papaya Linn. Asian Pacific Journal of Tropical Disease, 5, 1-6. https://doi.org/10.1016/S2222-1808(14)60617-4 